\title{
LUNG MECHANICS AND BLOOD GASES DURING ANAESTHESIA WITH SPONTANEOUS RESPIRATION*
}

\author{
Ney L. LouZada, M.D., M.SC., AND Davy Trop, M.D., M.sc. $f$
}

DURING THE PAST YEARS several authors have documented the progressive impairment in the mechanical and gas exchange properties of the lungs observed during anaesthesia. However, recent work ${ }^{1,2}$ has demonstrated that the main changes occur in the early period of the anaesthetic procedure and that lung parameters are not adversely affected in the later course.

In this study we have investigated the effects of anaesthesia on pulmonary efficiency, starting before premedication, and continuing into the recovery period. Each subject acts as his own control.

\section{Materual and Methods}

The observations were made on 20 adult patients without clinical or radiological evidence of respiratory or cardiovascular disease (Table I), who were anaesthetized for cerebral angiographic procedures. The patients had remained in bed for the previous twelve hours. On arrival in the induction room a no. 15 central venous pressure catheter was placed in the superior vena cava through a basilic or cephalic vein and an intravenous infusion of 0.85 per cent saline was started. A radial artery was cannulated with a no. 20 Argyll plastic needle and kept patent with heparinized saline.

At the same time an oesophageal balloon (length $10 \mathrm{~cm}$, perimeter $3.8 \mathrm{~cm}$ ) sealed over a catheter (i.d. $0.14 \mathrm{~cm}$, o.d. $0.19 \mathrm{~cm}$, length $85 \mathrm{~cm}$ ) was inserted through the nose to a position $45 \mathrm{~cm}$ from the nostril, and filled with $0.5 \mathrm{ml}$ of air. This was connected to one part of a 268 B Sanborn differential pressure transducer, the other part being attached to the patient's airway.

Respiratory flow was measured with a no. 2 Fleisch pneumotachograph and integrated electronically to show volume. Pressure, flow, and volume were displayed on a Honeywell uv Visicorder. Except for a short period of time following the intravenous injection of succinylcholine and the endotracheal intubation, all patients were allowed to breathe spontaneously from a non-rebreathing system using a Rudolph valve.

Inspired gas was sampled from the inspiratory limb of the anaesthetic machine; expired gas was collected simultaneously in a meteorologic bag. Blood and respiratory gases were analysed for $\mathrm{PO}_{2}$ and $\mathrm{PCO}_{2}$ in an $\mathrm{IL} 113$ gas analyser within

'Presented at the 1969 Annual Meeting of the Canadian Anaesthetists' Society. This study was supported in part by research grant 690044 from the Conseil de la Recherche Médicale du Québec, and grant 68/274-69/446 from FAPESP-São Paulo. This paper forms part of Dr. Louzada's M.sc. thesis for the Department of Experimental Medicine, McGill University.

tDepartment of Anaesthesia, Montreal Neurological Hospital and Institute, McGill University, Montreal. 
ten minutes of the sampling. Correction was made for temperature differences between the patient and the measuring electrode. The $\mathrm{Po}_{2}$ electrode was assumed to under-read by 2 per cent when blood was to be analysed, and the values were adjusted. $\mathrm{pH}$ was measured using an Astrup semi-micro apparatus.

A Beckman cardiodensitometer coupled to a 906 Harvard pump recorded the curve produced by the intravenous injection of $5 \mathrm{mg}$ indocyanine green, from which the cardiac output was calculated.

TABLE I

Age, Sex, Weight, and Height of the Patients

\begin{tabular}{ccccc}
\hline Patients & $\begin{array}{c}\text { Age } \\
\text { (years) }\end{array}$ & Sex & $\begin{array}{c}\text { Weight } \\
\text { (kg) }\end{array}$ & $\begin{array}{c}\text { Height } \\
\text { (cm) }\end{array}$ \\
\hline 1 & 53 & M & 90 & 185 \\
2 & 41 & M & 88 & 190 \\
3 & 41 & F & 57 & 160 \\
4 & 27 & M & 89 & 176 \\
5 & 50 & M & 70 & 179 \\
6 & 29 & M & 82 & 182 \\
7 & 42 & M & 82 & 190 \\
8 & 54 & M & 72 & 170 \\
9 & 34 & M & 83 & 178 \\
10 & 23 & F & 47 & 157 \\
11 & 48 & F & 71 & 170 \\
12 & 53 & F & 43 & 165 \\
13 & 29 & M & 75 & 168 \\
14 & 57 & F & 50 & 160 \\
15 & 36 & F & 97 & 165 \\
16 & 47 & M & 62 & 168 \\
17 & 52 & F & 44 & 152 \\
18 & 33 & M & 89 & 183 \\
19 & 49 & M & 103 & 175 \\
20 & 48 & F & 49 & 160 \\
& & & & \\
Mean & 42.3 & & 72.2 & 172.0 \\
S.D. & 10.3 & & 18.7 & 11.0 \\
\hline
\end{tabular}

Assuming $\mathrm{PACO}_{2}=\mathrm{Pa}_{\mathrm{CO}_{2}}, \mathrm{PA}_{\mathrm{O}_{2}}$ was calculated by the following equation:

$$
\mathrm{PA}_{\mathrm{O}_{2}}=\mathrm{PI}_{\mathrm{O}_{2}}-\mathrm{PA}_{\mathrm{CO}_{2}} \times \frac{\mathrm{PI}_{\mathrm{O}_{2}}-\mathrm{PE}_{\mathrm{O}_{2}}}{\mathrm{PE}_{\mathrm{CO}_{2}}}
$$

$\mathrm{AaDO}_{2}$ and $\mathrm{a} \overline{\mathrm{V}}_{2}$ were derived by subtraction. Assuming $\mathrm{Pc}_{\mathrm{O}_{2}}=\mathrm{PA}_{\mathrm{O}_{2}}$, physiological shunt was computed thus:

$$
\frac{\dot{\mathrm{Q}} \mathrm{s}}{\dot{\mathrm{Q}} \mathrm{t}}=\frac{\mathrm{C}_{\mathrm{O}_{2}}-\mathrm{Ca}_{\mathrm{O}_{2}}}{\mathrm{Cc}_{\mathrm{O}_{2}}-\overline{\mathrm{C}}_{\mathrm{O}_{2}}}
$$

Physiological dead space was derived from Bohr's equation:

$$
\mathrm{VD}=\mathrm{VT} \times \frac{\mathrm{Pa}_{\mathrm{CO}_{2}}-\mathrm{PE}_{\mathrm{CO}_{2}}}{\mathrm{~Pa}_{\mathrm{CO}_{2}}}-\mathrm{VD}_{\text {apparatus. }}
$$

Oxygen consumption was determined from Fick's equation:

$$
\dot{\mathrm{V}}_{\mathrm{O}_{2}}=\dot{\mathrm{Q}} \mathrm{t}\left(\mathrm{Ca}_{\mathrm{O}_{2}}-\mathrm{C}_{\mathrm{O}_{2}}\right) \text {. }
$$


Dynamic lung compliance was taken as a mean of five successive measurements. The paired $t$-test was used to compare each set of measurements with the preceding one.

All measurements were carried out in the supine position; the patients were breathing air when awake and a 50:50 $\mathrm{O}_{2} / \mathrm{N}_{2} \mathrm{O}$ mixture when anaesthetized. Five conditions were considered:

1. Before atropine.

2. $37 \pm 17 \mathrm{~min}$ after atropine (i.e. $0.015 \mathrm{mg} / \mathrm{kg}$ intravenous atropine).

3. $16 \pm 4 \mathrm{~min}$ after induction and intubation (i.e. $4.8 \pm 1.4 \mathrm{mg} / \mathrm{kg}$ Penthotal and $1.1 \pm 0.3 \mathrm{mg} / \mathrm{kg}$ succinylcholine, anaesthesia being maintained with $0.5-1.0$ per cent halothane).

4. $96 \pm 51 \mathrm{~min}$ after induction.

5. $38 \pm 11 \mathrm{~min}$ after the end of the anaesthesia (i.e. when complete consciousness was regained).

\section{Results (TABLe II)}

Dynamic lung compliance $\left(\mathrm{C}_{\mathrm{dyn}}\right)$ was unaffected by atropine, but decreased significantly after induction, from $124 \mathrm{ml} / \mathrm{cm} \mathrm{H}_{2} \mathrm{O}\left(\mathrm{f}=16\right.$ ) to $84 \mathrm{ml} / \mathrm{cm} \mathrm{H} \mathrm{H}_{2} \mathrm{O}$ $(f=27)$. No further impairment was noticed with time. After recovery the compliance increased but did not return to preoperative values $\left(98 \mathrm{ml} / \mathrm{cm} \mathrm{H}_{2} \mathrm{O}\right.$ at $\hat{\mathrm{f}}=18) . \mathrm{C}_{\mathrm{dyn}}$ measurements were repeated, before induction, at higher than normal frequencies $(f=26$ ) in 13 patients. Although the preoperative values were lower at these high frequencies, a subsequent fall in $\mathrm{C}_{\mathrm{dyn}}$ was observed after induction.

Atropine had no influence on the $\mathrm{VD}_{\mathrm{D}} / \mathrm{VT}_{\mathrm{T}}$ (from 0.32 to 0.30 ), but induction caused a highly significant increase of this parameter (from 0.30 to 0.53 ). Following recovery the VD/VT returned to its preoperative level $(0.32)$.

Q $s / Q t$ increased slightly after atropine (from 8.77 to 9.12 per cent) and markedly after induction (14.22 and 12.58 per cent). However, none of these changes reached the 5 per cent level of 'significance. After recovery no improvement was apparent.

The atropine effect on the Q in $\dot{Q}$ (from $4.19 \mathrm{~L} / \mathrm{min}$ to $3.92 \mathrm{~L} / \mathrm{min}$ ), which was highly significant. Recovery increased the Q $t$ to its preoperative level $(4.64 \mathrm{~L} / \mathrm{min})$.

$\dot{\mathrm{V}}_{2}$ and $\overline{\mathrm{avO}}_{2}$ were not significantly affected by atropine, but during anaesthesia a decrease in $\mathrm{Vo}_{2}$ (from $234 \mathrm{ml} / \mathrm{min}$ to $123 \mathrm{ml} / \mathrm{min}$ ), and in $\overline{a v o}_{2}$ (from 4.55 to 3.02 vol per cent) was observed. These values tended to return to their initial levels during the recovery period.

When similar $\mathrm{F}_{\mathrm{I}_{2}}$ values were considered, i.e. in the awake state or during anaesthesia, no changes in $\mathrm{AaDo}_{2}$ could be demonstrated. The increased $\mathrm{AaDO}_{2}$ observed with induction is biased by the increase in $\mathrm{FI}_{\mathrm{O}_{2}}$. The importance of this effect is discussed elsewhere. ${ }^{21}$

\section{Discussion}

$\mathrm{C}_{\mathrm{dyn}}$ was found to be decreased early after induction, and this reduction was sustained during anaesthesia. The values found are in agreement with those of 
TABLE II

Observed and Derived Data: Mean Values and Standard Deviation

\begin{tabular}{|c|c|c|c|c|c|}
\hline & $\begin{array}{c}\text { Before } \\
\text { premedication }\end{array}$ & $\begin{array}{c}\text { After } \\
\text { premedication }\end{array}$ & $\begin{array}{l}\text { Early } \\
\text { after } \\
\text { induction }\end{array}$ & $\begin{array}{c}\text { Late } \\
\text { after } \\
\text { induction }\end{array}$ & $\begin{array}{l}\text { After } \\
\text { recovery }\end{array}$ \\
\hline $\mathrm{VT}(\mathrm{m} 1)$ & $\begin{array}{r}662 \\
\pm 201\end{array}$ & $\begin{array}{l}520^{\prime \prime} \\
\pm 94\end{array}$ & $\begin{array}{l}340^{\prime \prime} \\
\pm 94\end{array}$ & $\begin{array}{r}356 \\
\pm 71\end{array}$ & $\begin{array}{l}492^{\prime \prime} \\
\pm 81\end{array}$ \\
\hline f (b.p.m.) & $\begin{array}{r}16.3 \\
\pm 4.8\end{array}$ & $\begin{array}{r}16.2 \\
\pm 3.1\end{array}$ & $\begin{array}{l}26.8^{\prime \prime} \\
\pm 6.0\end{array}$ & $\begin{array}{r}24.1 \\
\pm 3.6\end{array}$ & $\begin{array}{r}17.7 \\
\pm 3.7\end{array}$ \\
\hline$\dot{V}_{I}(\mathrm{~L} / \mathrm{min})$ & $\begin{array}{r}10.2 \\
\pm 3.1\end{array}$ & $\begin{array}{r}8.2 \\
\pm 1.5\end{array}$ & $\begin{array}{r}8.8 \\
\pm 2.4\end{array}$ & $\begin{array}{r}8.7 \\
\pm 2.0\end{array}$ & $\begin{array}{r}8.7 \\
\pm 2.5\end{array}$ \\
\hline $\mathrm{C}_{\mathrm{dyn}}\left(\mathrm{ml} / \mathrm{cm} \mathrm{H} \mathrm{H}_{2} \mathrm{O}\right)$ & $\begin{array}{r}126 \\
\pm 48\end{array}$ & $\begin{array}{r}124 \\
\pm 44\end{array}$ & $\begin{array}{l}84^{\prime \prime} \\
\pm 22\end{array}$ & $\begin{array}{r}81 \\
\pm 26\end{array}$ & $\begin{aligned} & 98^{\prime \prime} \\
\pm & 29\end{aligned}$ \\
\hline $\begin{array}{l}\mathrm{C}_{\mathrm{dyn}} \text { at increased } \mathrm{f} \\
\left(\mathrm{ml} / \mathrm{cm} \mathrm{H}_{2} \mathrm{O}\right)\end{array}$ & $\begin{array}{r}111 \\
\pm 44\end{array}$ & $\begin{array}{r}112 \\
\pm 43\end{array}$ & $\begin{array}{l}81^{\prime \prime} \\
\pm 22\end{array}$ & $\begin{array}{r}76 \\
\pm 25\end{array}$ & $\begin{aligned} & 94^{\prime} \\
\pm & 25\end{aligned}$ \\
\hline $\mathrm{VD}(\mathrm{ml})$ & $\begin{array}{r}208 \\
\pm 88\end{array}$ & $\begin{array}{l}158^{\prime} \\
\pm 48\end{array}$ & $\begin{array}{r}179 \\
\pm 56\end{array}$ & $\begin{array}{r}194 \\
\pm 56\end{array}$ & $\begin{array}{l}162^{\prime} \\
\pm 65\end{array}$ \\
\hline $\mathrm{V}_{\mathrm{D}} / \mathrm{VT}_{\mathrm{T}}$ & $\begin{array}{r}0.32 \\
\pm 0.05\end{array}$ & $\begin{array}{r}0.30 \\
\pm 0.07\end{array}$ & $\begin{array}{l}0.53^{\prime \prime} \\
\pm 0.11\end{array}$ & $\begin{array}{r}0.53 \\
\pm 0.11\end{array}$ & $\begin{aligned} & 0.32^{\prime \prime} \\
\pm & 0.09\end{aligned}$ \\
\hline Q்s/Q்t (\%) & $\begin{array}{r}8.77 \\
\pm 4.31\end{array}$ & $\begin{array}{r}9.12 \\
\pm 6.81\end{array}$ & $\begin{array}{r}14.22 \\
\pm 7.62\end{array}$ & $\begin{array}{r}12.58 \\
\pm 5.13\end{array}$ & $\begin{array}{r}14.93 \\
\pm 10.24\end{array}$ \\
\hline$\dot{\mathrm{Q}} \mathrm{t}(\mathrm{L} / \mathrm{min})$ & $\begin{array}{r}4.76 \\
\pm 1.12\end{array}$ & $\begin{array}{r}5.08 \\
\pm 1.24\end{array}$ & $\begin{aligned} & 4.19^{\prime \prime} \\
\pm & 0.97\end{aligned}$ & $\begin{aligned} & 3.92^{\prime} \\
\pm & 1.12\end{aligned}$ & $\begin{array}{l}4.64^{\prime \prime} \\
\pm 1.41\end{array}$ \\
\hline $\mathrm{a} \overline{\mathrm{v}} \mathrm{O}_{2}(\mathrm{vol} \%)$ & $\begin{array}{r}5.12 \\
\pm 1.32\end{array}$ & $\begin{array}{r}4.55 \\
\pm 1.24\end{array}$ & $\begin{array}{l}3.02^{\prime \prime} \\
\pm 1.06\end{array}$ & $\begin{array}{l}3.82^{\prime \prime} \\
\pm 0.73\end{array}$ & $\begin{aligned} & 4.54^{\prime} \\
\pm & 1.41\end{aligned}$ \\
\hline$\dot{\mathrm{V}} \mathrm{O}_{2}(\mathrm{ml})$ & $\begin{array}{r}242 \\
\pm 90\end{array}$ & $\begin{array}{r}234 \\
\pm 78\end{array}$ & $\begin{array}{r}123 \\
\pm 56\end{array}$ & $\begin{array}{r}140 \\
\pm 40\end{array}$ & $\begin{array}{r}210 \\
\pm 94\end{array}$ \\
\hline $\mathrm{PAO}_{2}$ (torr) & $\begin{array}{l}105.6 \\
\pm 8.6\end{array}$ & $\begin{array}{l}106.6 \\
\pm 9.4\end{array}$ & $\begin{array}{r}299.2 \\
\pm 35.1\end{array}$ & $\begin{array}{r}303.0 \\
\pm 23.4\end{array}$ & $\begin{array}{r}99.2 \\
\pm 10.5\end{array}$ \\
\hline $\mathrm{Pa}_{\mathrm{O}_{2}}$ (torr) & $\begin{array}{r}79.7 \\
\pm 10.8\end{array}$ & $\begin{array}{r}83.8 \\
\pm 10.2\end{array}$ & $\begin{array}{r}183.5 \\
\pm 39.0\end{array}$ & $\begin{array}{r}175.6 \\
\pm 36.6\end{array}$ & $\begin{array}{r}73.7 \\
\pm 12.3\end{array}$ \\
\hline $\mathrm{AaDO}_{\underline{2}}$ (torr) & $\begin{array}{r}26.0 \\
\pm 10.6\end{array}$ & $\begin{array}{r}24.7 \\
\pm 9.5\end{array}$ & $\begin{array}{r}115.7 \\
\pm 51.6\end{array}$ & $\begin{array}{r}127.4 \\
\pm 33.0\end{array}$ & $\begin{array}{r}25.6 \\
\pm 9.4\end{array}$ \\
\hline $\mathrm{PaCO}_{2}$ (torr) & $\begin{array}{r}36.8 \\
\pm 3.7\end{array}$ & $\begin{array}{r}36.1 \\
\pm 4.3\end{array}$ & $\begin{array}{l}45.0^{\prime \prime} \\
\pm 5.2\end{array}$ & $\begin{array}{r}44.9 \\
\pm 4.7\end{array}$ & $\begin{array}{c}39.6^{\prime \prime} \\
\pm 5.9\end{array}$ \\
\hline $\mathrm{pH}$ & $\begin{array}{r}7.43 \\
\pm 0.03\end{array}$ & $\begin{array}{r}7.43 \\
\pm 0.03\end{array}$ & $\begin{array}{l}7.36^{\prime \prime} \\
\pm 0.04\end{array}$ & $\begin{array}{r}7.35 \\
\pm 0.03\end{array}$ & $\begin{array}{l}7.39^{\prime \prime} \\
\pm 0.03\end{array}$ \\
\hline HR & $\begin{array}{r}74 \\
\pm 9\end{array}$ & $\begin{aligned} & 87^{\prime \prime} \\
& \pm 14\end{aligned}$ & $\begin{aligned} & 80^{\prime} \\
\pm & 11\end{aligned}$ & $\begin{array}{r}78 \\
\pm 8\end{array}$ & $\begin{array}{r}83 \\
\pm 8\end{array}$ \\
\hline $\mathbf{B A}_{\theta}$ (torr) & $\begin{array}{r}134 \\
\pm 24\end{array}$ & $\begin{array}{r}130 \\
\pm 23\end{array}$ & $\begin{array}{r}122 \\
\pm 30\end{array}$ & $\begin{array}{r}121 \\
\pm 19\end{array}$ & $\begin{array}{r}126 \\
\pm 17\end{array}$ \\
\hline
\end{tabular}

'Significant difference: $0.01<p<0.05$.

"Highly significant difference: $p<0.01$.

previous studies in anaesthetized, spontaneously breathing subjects. ${ }^{1,3-6}$ Gold and Helrich ${ }^{4,5}$ showed the decrease in $\mathrm{C}_{d y n}$ to appear six and ten minutes after induction. Wu, Miller, and $\mathrm{Luhn}^{6}$ observed a similar fall two hours after induction, as did Colgan and Whang, ${ }^{1}$ who, however, did not specify the time of their measurements.

In keeping with studies by Gold et al.,4,5 we noticed $\mathrm{C}_{\mathrm{dyn}}$ to decrease with lower VT values. Shallow tidal ventilation may in itself cause a fall in $\mathrm{C}_{\mathrm{dyn}}$ due to the closure of small airways at low inflation volumes. ${ }^{7}$ When the trapped 
gases are oxygen and nitrous oxide, as in the present study, rapid absorption and atelectasis are likely to occur. In the presence of airway closure and atelectasis, without changes in regional perfusion, one expects an increase in Q $\mathbf{s} / \dot{Q} t$. Increased physiological shunts of the same order of magnitude as the compliance changes were not detected in this study.

One is left with the possibility that the reduction of $\mathrm{C}_{\mathrm{dyn}}$ was related to distribution changes inside the airways. The anaesthetic drugs might affect the bronchomotor tone and the time constants of the millions of respiratory units, and/or might have an action on the surfactant with an increase in the surface tension inside the alveoli. In both situations one would expect physiological dead space to be increased, though $\dot{Q}$ s/Qt need not be affected, if there were concomitant falls in $\dot{Q} t$ and $\dot{V}_{O_{2}}$ as observed in the present work. Previous studies in man have not demonstrated any effect of anaesthetic agents on surfactant in similar conditions. ${ }^{8,9}$

No further deterioration in $\mathrm{C}_{\text {dyn }}$ was demonstrated up to 96 minutes after induction, a finding in keeping with the report of Colgan et al., ${ }^{1}$ who were unable to show any significant change up to 60 minutes after induction.

Endotracheal intubation is known to cut down the $V_{D_{\text {anat }}}$ by about $70 \mathrm{ml} .{ }^{10}$ As VD did not change after induction, an increase in $\mathrm{VD}_{\mathrm{alv}}$ must be accepted. The latter can be due to the above mentioned distribution changes and/or to irregularities in the $\dot{V}_{A} / \dot{Q} c$ relationship. Indeed, the observed fall in $\dot{Q} t$ could result in a decreased perfusion of the horizontally upper regions of the lungs, causing some alveoli to be well ventilated and poorly perfused.11

No progressive change in $\mathrm{PaO}_{2}$ could be demonstrated with anaesthesia, a finding in agreement with the reports of Gold et al. ${ }^{5}$ and Colgan et al. ${ }^{1}$ The mean $\mathrm{Pa}_{\mathrm{O}_{2}}$ measured in the postoperative period was lower than the preoperative value, as was $\mathrm{PAO}_{2}$; as a result $\mathrm{AaDO}_{2}$ did not change. Q $t$ and $\dot{\mathrm{V}}_{2}$ were on the average back to the preoperative values; $\mathrm{Pa}_{\mathrm{CO}_{2}}$ was slightly higher. The most likely explanations for this fall in $\mathrm{Pa}_{\mathrm{O}_{2}}$ are hypoventilation and/or the nitrous oxide elimination phenomenon, diluting the oxygen in the alveoli. Our postoperative results agree with those of Stephen and Talton, ${ }^{12}$ who reported arterial hypoxaemia in all their patients allowed to breathe room air in the immediate postoperative period, as well as with the findings of Bay, Nunn, and Prys-Roberts ${ }^{13}$ and Nunn and Payne. ${ }^{14}$

The lack of progressive changes in $\dot{\mathrm{Q}} \mathrm{s} / \dot{\mathrm{Q}} \mathrm{t}$ and $\mathrm{AaDo}_{2}$ observed up to 96 minutes in the anaesthetized state is in agreement with the reports of Marshall ${ }^{15}$ and Panday and Nunn, ${ }^{2}$ who were unable to detect any significant deterioration of these parameters for periods up to 70 and 60 minutes respectively. However, it should be emphasized that, although no significant difference could be demonstrated between any set of $\dot{Q} s / \dot{Q} t$ measurements and its preceding one, 13 of 16 patients showed an increase in this parameter when the set obtained late after induction was compared with those obtained before induction.

$\dot{Q} s / \dot{Q} t$ values in awake subjects breathing air are the result of both $\dot{V}_{A} / \dot{Q} c$ inequalities and physiological shunt, as diffusion limitation does not play an important role with $\mathrm{P}_{\mathrm{A}_{2}}$ at or above 100 torr. ${ }^{16}$ When the patient breathes 50 per cent oxygen, the distribution component is thought to be eliminated. ${ }^{17}$ 
Although Q̇s/Q்t did not change significantly during anaesthesia, the possibility remains that some atelectatic areas developed, but that their effect on the venous admixture was offset by the decrease in the distribution component after $\mathrm{O}_{2}$ breathing. This hypothesis is not supported by the absence of changes in $\mathrm{AaDO}_{2}$ results, which we reported elsewhere. ${ }^{21}$ As a distribution component cannot be invoked, one must therefore consider that the same degree of atelectasis, if any, is present before and after induction.

However, the somewhat unlikely possibility cannot be excluded of a progressive increase in venous admixture occurring along with a decrease in the distribution component, as low $\dot{\mathrm{V}}_{\mathrm{A}} / \dot{\mathrm{Q}}_{\mathrm{c}}$ areas keep washing out part of their nitrogen.

A decrease in $\dot{\mathrm{Q}} \mathrm{t}$ will magnify the effects of any given $\dot{\mathrm{Q}}_{\mathrm{s}} / \dot{\mathrm{Q}}_{\mathrm{t}}$ on $\mathrm{AaDo}_{2}$, provided the $\dot{\mathrm{V}}_{2}$ is constant. ${ }^{18}$ If both $\dot{\mathrm{Q}} \mathrm{t}$ and $\dot{\mathrm{V}}_{2}$ fall at the same rate, the difference $\mathrm{Ca}_{\mathrm{O}_{2}}-\mathrm{C}_{\mathrm{O}_{2}}$ will remain unchanged. Actually a decrease in both parameters was found, and this was consistent with the failure to demonstrate any significant change in $\dot{\mathrm{Q}} \mathrm{s} / \mathrm{Q} \mathrm{t}$. The $\dot{\mathrm{V}}_{2}$, however, fell proportionally more than the $\dot{\mathrm{Q}} \mathrm{t}$, as demonstrated by the decrease in $\mathrm{Ca}_{\mathrm{O}_{2}}-\mathrm{Cv}_{\mathrm{O}_{2}}$ with anaesthesia; but the expected decrease in $\mathrm{AaDO}_{2}$ was not observed. This may be the consequence of assuming the oxygen content of the svc to be equal to the $\mathrm{Cv}_{0_{2}}$. The direction of changes, however, in $\mathrm{C}_{\mathrm{V}_{2}}$ may validly be sensed by samples obtained from the svc. ${ }^{19}$

The lack of correlation between the changes in $\mathrm{C}_{\mathrm{dgn}}$ and $\dot{\mathrm{Q}} \mathrm{s} / \dot{\mathrm{Q}} \mathrm{t}$ confirms the findings of Collier and Mead in dogs. ${ }^{20}$

In conclusion, three major observations were made:

1. Induction of anaesthesia was followed by a fall in $\mathrm{C}_{\mathrm{dyn}}$, probably due to a change in the time constants of the different parts of the lungs. Atropine and progression of anaesthesia up to 96 minutes did not alter $C_{d y n}$ to any significant degree.

2. $\dot{\mathrm{Q}} \mathrm{s} / \mathrm{Q} t$ measurements were not different at any stage of the study, despite the fact that $\mathrm{Q}$ f fell during anaesthesia. The concomitant and probably proportional decrease in $\dot{V}_{2}$ seems a valid explanation for this finding. It should be stressed, however, that 13 of 16 patients showed an increased Qs/Qt late after induction, when values were compared with the preinduction ones. A closure of some units is thus suggested.

3. No significant changes in $\mathrm{AaDo}_{2}$ were observed with atropine during the course of anaesthesia or after recovery, at identical $\mathrm{Fr}_{\mathrm{O}_{2}}$.

\section{SUMMARY}

Lung mechanics and blood gases were studied throughout the course of anaesthesia in 20 patients undergoing cerebral angiographic procedures. Measurements started before premedication and continued into the recovery period, each subject acting as his own control.

Premedication $\left(0.015 \mathrm{mg} / \mathrm{kg}\right.$ atropine) did not affect $\mathrm{C}_{\mathrm{dyn}}, \dot{\mathrm{Q}} \mathrm{s} / \dot{\mathrm{Q}} \mathrm{t}$, and $\mathrm{AaDo}_{2}$. Induction of anaesthesia resulted in a significant fall in $\mathrm{C}_{\text {dyn }}$, but no alteration in $\dot{\mathrm{Q}} / \mathrm{Q} \mathrm{t}$. There were no changes in $\mathrm{C}_{\mathrm{dyn}}, \dot{\mathrm{Q}} \mathrm{s} / \mathrm{Q} \mathrm{t}$, and $\mathrm{AaDo}_{2}$ up to 96 minutes after induction. $\mathrm{C}_{\mathrm{dyn}}$ returned to preoperative values during the recovery period, and $\dot{\mathrm{Q}} \mathrm{s} / \dot{\mathrm{Q}} \mathrm{t}$ and $\mathrm{AaDo}_{2}$ remained unaffected. 
The fall in $\mathrm{C}_{\mathrm{dyn}}$ was probably due to a change in the time constants of the different parts of the lungs. The concomitant and probably proportional decrease in $\dot{Q} t$ and $\dot{\mathrm{V}}_{2}$ seems a valid explanation for the lack of changes in $\dot{\mathrm{Q}} / \dot{\mathrm{Q}} \mathrm{t}$. Thirteen out of sixteen patients, however, showed an increased $\dot{Q} s / \dot{Q} t$ late after induction, when values were compared with the preinduction ones. A closure of some units is thus suggested.

\section{RÉSUMÉ}

Les valeurs de compliance pulmonaire et des gaz sanguins furent relevées chez 20 patients anesthésiés pour des examens angiographiques cérébraux. Les observations commencèrent avant toute prémédication et se poursuivirent jusqu'à la période du réveil dans chaque cas.

L'injection intraveineuse d'atropine n'eut aucun effet sur la compliance dynamique, le shunt ou le gradient alvéolo-capillaire. L'induction anesthésique provoqua une diminution de la compliance, mais n'affecta pas le shunt. Les valeurs de la compliance, du shunt et du gradient alvéolo-capillaire, relevées après 96 minutes d'anesthésie, ne présentèrent aucune altération subséquente. Au réveil, la compliance redevint normale, tandis que le shunt et le gradient restaient inchangés.

La diminution de la compliance est imputable aux variations de constante de temps à l'intérieur des poumons. Les changements simultanés et parallèles du débit cardiaque et de la consommation d'oxygène foumissent une explication satisfaisante à l'absence de variation observée dans le shunt.

Treize patients sur seize cependant présentèrent une augmentation du shunt lorsque les valeurs peranesthésiques furent comparées aux valeurs de contrôle. Ceci semble indiquer la fermeture de certains segments pulmonaires.

\section{ACKNOWLEDGMENTS}

Grateful thanks are expressed to Dr. R. G. B. Gilbert and Dr. M. R. Becklake for their kind advice. The technical assistance of Mrs. Lise Davignon and Mr. Shew Chang Wong is gratefully acknowledged.

\section{REFERENCES}

1. Colgan, F. J. \& Whang, T. B. Anesthesia and Atelectasis. Anesthesiology. 29: 917 (1968).

2. Panday, J. \& Nunn, J. F. Failure to Demonstrate Progressive Falls of Arterial $\mathrm{Po}_{2}$ during Anaesthesia. Anaesthesia. 23: 38 (1968).

3. Gold, M. I. \& Helrich, M. Pulmonary Compliance during Anaesthesia. Anesthesiology. 26: 281 (1965).

4. Gold, M. I. \& Herrich, M. Mechanics of Breathing during Anesthesia: II. The Influence of Airway Adequacy. Anesthesiology. 26: 751 (1965).

5. Gold, M. I.; HaN, Y. H.; \& Helruch, M. Pulmonary Mechanics during Anesthesia: III. Influence of IPPB and Relation to Blood Gases. Anesth. \& Analg. 45: 631 (1966).

6. Wu, N.; MmLer, W. F.; \& LuHN, N. R. Studies of Breathing in Anesthesia. Anesthesiology. 17: 696 (1956).

7. Butler, J.; White, H. C.; \& ARnotr, W. M. Pulmonary Compliance in Nomal Subjects. Clin. Sc. 16: 709 (1957). 
8. Patterson, R. W.; Sullivan, S. F.; Malm, J. R.; Bowman, F. O.; \& Papper, E. M. The Effect of Halothane on Human Airway Mechanics. Anesthesiology. 29: 900 (1968).

9. Nishimura, N. \& Metori, S. Some Considerations of the Effect of Gaseous Anesthetic Agents on Pulmonary Compliance. Anesth. \& Analg. 46: 187 (1967).

10. Nunn, J. F.; Campbelt, J. M.; \& Peckett, B. W. Anatomical Subdivisions of the Volume of Respiratory Dead Space and Effect of Position of the Jaw. J. Appl. Physiol. 14: 174 (1959).

11. Kaneko, K.; Milic-Emal, J.; Dolovich, M. B.; Dawson, A.; \& Bates, D. V. Regional Distribution of Ventilation and Perfusion as a Function of Body Position. J. Appl. Physiol. 21: 767 (1966).

12. Stephen, C. R. \& Talton, I. Immediate Postoperative Care, with Particular Reference to Blood-gas Studies. Canad. Anaesth. Soc. J. 11: 586 (1964).

13. Bay, J; Nunn, J. F.; \& Prys-Roberts, C. Factors Influencing $\mathrm{Pa}_{\mathrm{O}_{2}}$ during Recovery from Anaesthesia. Brit. J. Anaesth. 40: 398 (1968).

14. Nunn, J. F. \& Payne, J. P. Hypoxaemia After General Anaesthesia. Lancet. ii: 631 (1962).

15. Marshall, B. E. Physiological Shunting and Dead Space during Spontaneous Respiration with Halothane-oxygen Anaesthesia and the Influence of Intubation on the Physiological Dead Space. Brit. J. Anaesth. 38: 912 (1966).

16. Fanhi, L. E. \& Rarn, H. A Theoretical Analysis of the Alveolar-arterial $\mathrm{O}_{2}$ Difference with Special Reference to the Distribution Effect. J. Appl. Physiol. 7: 699 (1955).

17. Asmussen, E. \& Nielsen, M. Alveolo-arterial Gas Exchange at Rest and during Work at Different $\mathrm{O}_{2}$ Tensions. Acta Pysiol. Scandinav. 50: 153 (1960).

18. Kelman, G. R; Nunn, J. F.; Prys-Roberts, C.; \& Greenbaum, R. The Influence of Cardiac Output on Arterial Oxygenation: A Theoretical Study. Brit. J. Anaesth. 39: 450 (1967).

19. Theye, R. A. \& Tuohy, G. F. The Value of Venous Oxygen Levels during General Anesthesia. Anesthesiology. 26: 49 (1965).

20. Collier, C. R. \& Mead, J. Pulmonary Exchange as Related to Altered Pulmonary Mechanics in Anesthetized Dogs. J. Appl. Physiol. 19: 659 (1964).

21. Louzada, N. L. \& Trop, D. The Effect of the $\mathrm{FI}_{\mathrm{O}_{2}}$ on the $\mathrm{AaDo}_{2}$ during Anaesthesia. Canad. Anaesth. Soc. J. (In press.) 